\title{
NEXUS BETWEEN HUMAN CAPITAL AND ECONOMIC GROWTH: EVIDENCE FROM GROWTH MODEL IN PAKISTAN
}

\author{
Zia-ur-Rahman*, Saleem Khan $†$ \& Sher Ali $\ddagger$
}

\begin{abstract}
In the global economy, every country wants to boost the economic development of the economy in the nation. In this, good governance can play significant role in development of the economy. The present study aims at investigating the impact of human and physical capital on economic growth in Pakistan. Annually time series data is used for analysis during the period of 1980-2016. The data has been taken from the 'Pakistan Economic Survey' and 'A Handbook of Statistics 2015'. The ADF (Augmented Dickey-fuller) test is used for stationary and non-stationary process. For parameters estimation and co-integration, the Engle-Granger approach is used to indicate that there is long-run connection among the study concerned variables. The empirical finding of this study demonstrated that gross fixed capital formation, literacy rate, per-capita health expenditure and secondary school enrolment rate have a significant impact on the economic growth of Pakistan. There is co-integration among variables of the model.
\end{abstract}

Keywords: Human capital, physical capital, Co-Integration, ADF test and Pakistan.

\footnotetext{
* MS Scholar, Department of Economics, Gomal University Dera Ismail Khan, Email: ziaeco20@gmail.com.

+ Assistant Professor, Department of Economics, Abdul Wali Khan University Mardan.

₹ Assistant Professor, Department of Economics, Islamia College Peshawar.
} 


\section{Introduction}

There are hundreds of indicators which can accelerate the economic progression of a nation state. Economic indicators include, such as foreign direct investment, worker remittances, foreign aid, exports and imports, domestic investment and savings, factor productivity, and investment in health and literacy etc. It is reported in literate that the core factor of economic growth is labour and capital (Solow, 1956). The gross fixed capital formation represents over-all wealth stock of a state. It is investment that can rise assets stock of a nation. Investment is the back bone for the development of the economic growth of any country, either developed or developing country. Public investment is more important in the long run that is not only providing education, health, infrastructure but can also increasing the private investment in the economy. It is argued that the investment from the Government has significant role in the development of the economy. Public investment can increase the production of good and services in an economy, creating the employment in the country and also increase the national income. Instead of physical capital, the current research focuses on investment in human capital in form of training, education and health etc. Countries have strong education systems make sure a quality workforce and this can translate into higher economic growth.

Romer and Weil (1992) reported that human capital shows a business role in economic growth model. When the education and health are at door step then automatically the economic growth will increase because when the labour force are educated and healthy, then there will be increase in productivity level in the country. Endogenous growth model said that, the investment in the human capital is more than the investment in the physical capital. These variables are modelled in growth equations for the role of economic growth in the country. That's how these variables are more important for the development of the country.

Iqbal and Zahid (1998) and Azam and Ahmed (2010), focus taking place that investment in the human capital for the improvement of the economy. They suggested that expenditure on human resources can improve the national human capital, and in turn can increase the financial development and advance the economy of the nation. Investment in human capital can increase productivity of workers because of the high quality education and health.

Moreover, human capital is not limited to knowledge or education. In many research studies, healthiness takes remained exposed to be progressive element and record important donor to economic growth of a country 
(Bloom and Canning 2000, 2003). Considering only as the life expectancy, in several years human capital can affect the economic progress, because whenever general public living long, they will save extra for their old stage. Despite the theoretical significance that human capital can effect economic growth, the empirical evidence is mixed. Some studies report that the role of human capital is insignificant for labour abundant countries. It is also reported that public spending on education crowd out private spending (Blankenau and Simpson, 2004).

Shortly, any state that wants to increase the economic growth of the nation state. The Government should invest in the new industries or up gradation of technology then it can create employment and increase capital formation and the national income level. So for that, the government should invest in the education and health sectors as well. When if the labour force are educated, skilful, and they have standard health facility available in the country, so automatically the productivity will be more in the economy. There are many empirical studies from cross country analysis and time series enquiry, and the empirical signal is very mix. Moreover, time series analysis of human capital and economic growth model give more accurate estimate than cross country evidence.

Therefore, the present study estimates a time series model of physical capital, human capital and economic growth for the economy of Pakistan over the period of 1980 to 2016. Pakistan has low income economy and invested relative low in education over the last few decades, thus the country's case is important for understanding the association among human capital and economic growth. The study model the effect of both human and physical capital on economic growth of the country, provides estimates of profit to human and physical capital.

\section{Problem Statement}

Pakistan's economic growth is dynamic not static. By observing data, it can be seen that the economy growth rate on average is around 4 percent for the last few decades. However, decade wise this growth rate has fluctuated between greater as well as smaller for different decades. For instance, since the independence, growth rate on average remained 6.8 percent in $1960 \mathrm{~s}, 4.8$ percent in 1970s while 6.5 percent in the 1980s and this declined for the afterward period. In the last decade, the growth rate also shows a cycle as the highest rate of growth and lowest for different years. Many factors are responsible for this high and low rate of the development in the economy. 
However, in the view of this investigation we are examining the connection between growth rate and human capital of the country.

\section{Objectives of the Study}

Human capital and physical capital are considered as the backbone of the economic growth of the country, but unfortunately in Pakistan investment level is very low in education. We are going to examine that how both human capital and physical capital can affect the economic growth of the country. Thus the major objectives are as given:

1) To analyse for the trend behaviour of human capital and physical capital in last thirty-five years.

2) To investigate the impact of human capital and physical capital on economic growth of Pakistan.

\section{Hypothesis of the Study}

1. H1: There is no significant relationship between human capital and economic growth of the country.

2. H2: There is no significant relationship between physical capital and economic growth of the country.

\section{Literature Review}

Several works have been examined to estimate the interrelationship among human capital, physical capital and economic development of different nations. The interest is the estimation of the impact of these variables on the economic development of the country which helping to increase the GDP of the economy. Furthermore, literature suggest that, investment in the human capital can help in the development of the human resources such as literacy, health, skill, experience of the new technology. Investment in the physical capital is the beneficial key for the economic development or growth which created new job opportunities, new capital formation etc. Previous literature about these basic factors of economic growth is organized in the following sections.

\section{Human Capital and Economic Growth}

Romer (1986) and Lucas (1988), growth model of economy said that investment in the human resources is a significant key factor in the 
development of the economy of nations. Investment in the human resources can also increase the economic growth or development in the nations in the long run and also in the short run. If the work force is educated and healthy, then the economy will boost to the maximum point through increase in the productivity of good and services because of the educated and skilful workers in the country. The significant addition of the individuals plays significant role in the economy. Investment in human resources also plays vital part in the economic growth by investment in the physical capital which increased the per-capita income growth. Because when the workers are educated and healthy and they are able to understand new technology machinery in the economy, so then the investment in the country will also increase. The physical capital is also dependent on the investment in the human resources because when the labour force is educated, then there will be increase in investment in the physical resources to increase the productivity and economic development of the economy in the nation state. Lucas (1990) said that the investment in the capital formation in the economically poor economies is very low because of the uneducated and unhealthy workers. In economically bad economies, the Government should invest in the human capital to provide them education and health centres. When the workers are educated and healthier, then they work and increase the productivity in the economy.

Mankiw et al. (1992) studied that the effect of the human capital in the economic development of the economies is positive. For that analysis, Mankiw used the country-cross analysis. Mankiw examined that the investment in the human capital is playing effective role in the economic development of the country. For that measurement, he focused on the enrolment rate in the secondary schools. He suggested that education in the economy plays an essential role in the improvement of the economic growth in the state. When the investment is made in education and health sectors which embody human capital, it will resultantly increase the economic growth of the economy. So the Government should increase investment in education to provide more education institutes and which should be easily affordable by the people of the country. If the education is easily accessible for the nation then the enrolment rate in the schools will increase by taking more admissions in the schools. By the increment in the enrolment rates in the schools, the literacy rate in the economy will also boost.

Bils and Klenow (2000) examined the interrelation between human resources (enrolment rate in schools) and economic development. They concluded that if a country has high enrolment rate means high number of students in the schools then the economic growth of the country will be 
greater. Because when enrolment is high then the educated people in the country is high, and then the workers will understand the new technology or machinery easily. When the enrolment rate is high in the country, the economic growth of the country also increases by educated as well as skilled full labour force. Education can also effect the economy in the long run because today's investment in education is tomorrow's profit by educated and skilful labour available on behalf of the production of goods and services in the economy which have an encouraging effect on economic progression. They expressed that education is the only key factor to increase the economic progress in the long run and short run as well. Agiomirgianakis et al. (2002) found the relation between education and economic, and said that education has a strong progressive impact on the economic growth of the economy by using large panel data technique. $\mathrm{He}$ also studied that the higher education can increase the productivity and percapita income of the country. Amjad (2005) claimed that investment in the human capital also increases the investment in the physical capital because of the educated workers in the economy for that introduce new equipments in the industries. Khan's (2005) results also reveal that compared to a large group of states, Pakistan's performance in terms of per capital economic development has remained healthier than normal for the duration of the period of study analysis and approximately similar to that of other states in South Asia. Qadri and Waheed (2011) surveyed the connection between human capital and economic growth via education and health as indicators. They used data for the period of 1978-2007 by employing Johansen Cointegration approach for estimation purpose. The results found that there is co-integration between human capital and economic growth of Pakistan.

\section{Physical Capital and Economic Growth}

Aschauer (1989a, 1989b) expressed that the public capital is a key factor for the economic growth of the nations. The economic growth of the nation can only by the investment in the public capital. Public capital is the most important aspect for the improvement of the national growth. When the investment increases in the country by establishing new industries or business, it can increase employment rate and can also increase the productivity in the country. Investments are made to create new assets either physical or financial assets. Capital formation means introduction of new industries, companies etc. Some of the examination suggested that the public investment may be negatively or positively affecting the economic growth 
but private investment has a significant outcome in the economic growth of the nation.

Mittnik and Newman (2001) expressed that investment from the government side is for the public and economic welfare, and plays major part in the improvement of the economy. If the government decrease investment level then it will be very harmful for the economic growth of the country economy. Aubyn and Afonso (2008) found that the effect of both public and private investment is significant and has strong positive effect on the GDP, inflation and employment. Public investment can also encourage the private investors as well in the country. Falki (2009) examined that the impact of foreign direct investment on economic development of Pakistan has a significant role in the economy, data which is used for the period of 1980 to 2006. By using the production function approach, he further examined that the foreign direct investment effects the economic growth and other variables also like trade, domestic capital and labour positively effecting the economy. So the government of Pakistan should make the country peaceful and attractive to invest more in the economy from the foreign investors and domestic investors to enhance the economic growth of the country. Shuaib and Peter (2010) examined that the financial institution and investment is very helpful and play significant role in the development of the economic growth of the economy. Financial institution borrows money from the investors and invest that money for the benefit in the future which help to increase the economic growth. Financial institution also invests that money in the neglected sectors to create job opportunities for the unemployed people and also decreases poverty, Dutch disease of an economy and also decrease inflation in the economy.

\section{Data and Methodology}

\section{The Data}

In this research, annual data is used for analysis. There are total 37 observations and time period of the study is 1980-2016. Mostly, the data has been used in nominal term. The data can be obtained from different databases either national or international. However, here the data for different variables of the study has been taken form the following recognized databases of the country.

a) Pakistan Economic Survey (various issues)

b) A Handbook of Statistics 2015, Published by State Bank of Pakistan 


\section{The Model of Study}

This research examines the impact of Human capital and Physical capital on the economic growth of Pakistan. Basically the idea for the development of the econometric model to study the connection among the human capital, physical capital and its impact on the economic evolution of Pakistan are actually taken from the Romer (1986) and Lucas (1988) growth models. And also the basic idea taken from the Anderson (1990) study in which he said that investment in the physical capital is the key reason for the improvement of the economy. So the economic model for analysis can be written in functional form as given:

$$
G D P=F(G F C F, P C H E, L R, S S E R,)
$$

As GDP is the dependent variable and all additionals are independent variables. For estimation purpose, we are taking log both side and estimate for the following specifications:

$$
\begin{gathered}
\ln G D P=\alpha_{0}+\alpha_{1} \ln G F C F+\alpha_{2} \ln L R+\mu \\
\ln G D P=\alpha_{0}+\alpha_{1} \ln G F C F+\alpha_{2} \ln L R+\alpha_{3} \ln S S E R+\mu \\
\ln G D P=\alpha_{0}+\alpha_{1} \ln G F C F+\alpha_{2} \ln L R+\alpha_{3} \ln S S E R+\alpha_{4} \ln P C H E+\mu
\end{gathered}
$$

Where, the variables which are included in the models are as given:

$$
\begin{aligned}
& \text { GDP = Gross Development product. } \\
& \text { GFCF = Gross Fixed Capital Formation } \\
& \text { PCHE = Per-Capita Health Expenditure. } \\
& \text { LR = Literacy Rate. } \\
& \text { SSER = Secondary School Enrolment Rate. }
\end{aligned}
$$

All variables are in natural $\log$. GFCF is used to represent physical capital of the country and the other three are used to represent human capital of the country. Economic theory requires that $\alpha_{1}>0, \alpha_{2}>0, \alpha_{3}>0$ and $\alpha_{4}>0$, etc.

\section{Methodology}

To execute the empirical analysis, for instance, descriptive analysis, unit root analysis and the most important regression analysis are considered. This study employs different econometric tests and techniques. First this study used descriptive statistics to find the mean, median and variance of the series and, then employed unit root to test for stationarity. 
Unit Root: Since then after, unit root will be tested for each series of the model. The aim is to test either variable of the study is stationary or nonstationary at the level. For this purpose will employ Augmented Dickey Fuller (ADF) Test. The ADF test assume null hypothesis of no unit root in the series. If the test statistics is greater than the critical values, then we will deny the null and accept the alternative hypothesis of unit root in the series. In case of stationary series at level, we will use the simple regression analysis. In case of integrated first order we will use the co-integration approach of Engle-Granger (EG).

Engle-Granger (EG) Co-integration: Once we find that all series of the study are integrated first order then the EG approach will be employed to estimate the selected regression model. Mostly in the time series data all the selected variables are stationary or integrated first order i.e. I (1) variables. It follows that, any equilibrium theories that include non-stationary variables require the presence of a mixture of the variable to be stationary. That means that the residual from the regression will be stationary. For instance, in our case we can say that GDP and the independent variables are co-integrated, if the residuals from regression (4) is stationary or of integrated zero order i.e. I (0). As once we estimate regression (4) and get the residuals. Then test the residuals for unit root using ADF test and originate that the residuals are stationary at level. Thus, in our case we can say that the variables in regression model exhibit co-integration or there is long run relationship.

\section{Results and Discussion}

Descriptive Statistics: Descriptive statistic is mainly used for the summarization of the data from the sample of the population as to find the mean value, median, maximum, minimum and variance etc. In the table-1 of descriptive statistics, the analysis of the data is carried out in a detail. Data period is from 1980 to 2016 which is 37 years data. The descriptive statistic illustrate that the average of per-capita income (PCI) is 11.31737 with the standard deviation of 1.088138. The average of literacy rate (LR) is 4.09984 with the standard deviation of 0.33212 . The average of the primary school enrolment rate (PSER) is 5.042896 with the standard deviation of 0.25091. The average of the per-capita health expenditure (PCHE) is 4.223887 with the standard deviation of 1.08155 . The average of the gross fixed capital formation (GFCF) is 13.32034 with the standard deviation of 1.43500 . 
Table 1: The Results of Descriptive Statistics for all Variables

\begin{tabular}{|l|c|c|c|c|c|}
\hline & LNPCI & LNLR & LNPSER & LNPCHE & LNGFCF \\
\hline Mean & 11.31737 & 4.09984 & 5.042896 & 5.223887 & 13.64544 \\
\hline Median & 10.237662 & 4.220860 & 6.006625 & 5.0896410 & 12.341398 \\
\hline Maximum & 12.43859 & 5.009345 & 5.111385 & 6.836689 & 13.94760 \\
\hline Minimum & 8.040125 & 3.259164 & 4.080922 & 2.443216 & 10.58089 \\
\hline $\begin{array}{l}\text { Standard } \\
\text { Deviation }\end{array}$ & 1.0889138 & 0.33212 & 0.250491 & 1.081955 & 1.435200 \\
\hline Observations & 37 & 37 & 37 & 37 & 37 \\
\hline
\end{tabular}

Mean: Mean of literacy rate is 4.09984 , which is less and mean of gross fixed capital formation is 13.645444 which is greater that from the other variables.

Standard deviation: Standard deviation of literacy rate is 0.33212 which is less and standard deviation of gross fixed capital formation is of value 1.435200 which is higher than the standard deviation of all the other variables.

\section{Unit Root Analysis}

The Augmented Dicky-Fuller test is actually a unit root test to check the data for stationarity when the data is intime series. The ADF test assumes the null hypothesis of no unit root and an alternative hypothesis of unit root. Once the test statistics does not reject the null hypothesis then take it and the series is said to be stationary. Alternatively, once the test statistics is greater than the critical value and rejects the null hypothesis, then the unit root hypothesis is accepted and concludes that the series is non stationary at level. Thus, ADF test are tested for all variable at level as well as at first difference. All variables are looking stationary after first difference. The results are reported in Table- 2 and Table-3. 
Table 2: Unit Root Results at Level Using ADF Test with Constant and Trend

\begin{tabular}{|l|c|c|c|}
\hline Variable & Test-statistics & $\begin{array}{c}\text { C.V at 1 } \\
\text { percent }\end{array}$ & $\begin{array}{c}\text { C.V at 5 } \\
\text { percent }\end{array}$ \\
\hline RGDP & $-2.4863(0.3699)$ & -4.283644 & -3.554284 \\
\hline GFCF & $\begin{array}{c}-2.144413 \\
(0.5059)\end{array}$ & -4.255644 & -3.577284 \\
& $1.5398(1.0000)$ & -4.262735 & -3.552973 \\
\hline LR & -2.167170 & -4.243644 & -3.544284 \\
\hline SSER & $(0.4922)$ & & \\
\hline PCHE & $-3.3072(0.9995)$ & -2.6369 & -1.9513 \\
\hline
\end{tabular}

Note. \# indicate the regression with none i.e. no trend and no intercept

Table 3: Unit Root Results at First Difference using ADF Test with Constant and Trend

\begin{tabular}{|l|c|c|c|}
\hline Variable & Test-statistics & $\begin{array}{c}\text { C.V at 1 } \\
\text { percent }\end{array}$ & $\begin{array}{c}\text { C.V at 5 } \\
\text { percent }\end{array}$ \\
\hline$\Delta$ RGDP & $-4.4295(0.0065)^{*}$ & -4.252879 & -3.548490 \\
\hline$\Delta$ GFCF & -5.910659 & -4.252879 & -3.548490 \\
& $(0.0001)^{*}$ & & \\
\hline$\Delta$ LR & $-3.5593(0.0493)^{* *}$ & -4.262735 & -3.552973 \\
\hline$\Delta$ SSER & -6.604483 & -4.252879 & -3.548490 \\
& $(0.0000)^{*}$ & & \\
\hline$\Delta$ PCHE & $-5.0559\left(0.0000^{*}\right)$ & -2.6369 & -1.9513 \\
\hline
\end{tabular}

Note: The * and $* *$ represents one and five percent level of significance, respectively.

$1 \%$ level of significance represents $99 \%$ of confidence level.

$5 \%$ level of significance represents $95 \%$ of confidence level.

$10 \%$ level of significance represents $90 \%$ of confidence level.

RGDP: at level t-test value is less than critical value while at first difference $\mathrm{t}$-test value is greater than critical value. At first difference, the t-test value is -4.429 and critical value is -4.252 .

Therefore, rejects the null hypothesis of no unit root at level while accepts at first difference. It is concluded that the real GDP is stationary at first difference at 1 percent level of significance. 
GFCF: at level t-test value is less than critical value while at first difference t-test value is greater than critical value. At first difference t-test value is 5.9106 and critical value at 1 percent is -4.252 .

Therefore, rejects the null hypothesis of no unit root at level while accepts at first difference. It is concluded that the gross fixed capital formation (GFCF) is stationary at first difference at percent level of significance.

LR: at level t-test value is less than the critical value while at first difference t-test value is greater than critical value. At first difference the t-test value is -3.559 and critical value is -3.552 .

Therefore, rejects the null hypothesis of no unit root at level while accepts at first difference. It is concluded that the literacy rate (LR) is stationary at first difference at 5 percent level of significance.

SSER: at level t-test value is less than critical value while at first difference $\mathrm{t}$-test value is greater than critical value. At first difference the t-test value is -6.604 and critical value is -4.252 .

Therefore, rejects the null hypothesis of no unit root at level while accepts at first difference. It is concluded that the secondary schools enrolment rate (SSER) is stationary at first difference at 1 percent level of significance.

PCHE: at level t-test is less than critical value while at first difference t-test value is greater than critical value. At first difference t-test value is -5.0559 and critical value at 1 percent is -2.636 .

Therefore, rejects the null hypothesis of no unit root at level while accepts at first difference. It is concluded that the per-capita health expenditure (PCHE) is stationary at first difference at 1 percent level of significance.

Shortly, all variable are tested for unit root at level and at first difference. The results indicate that all variables are stationary at first difference, which means that each series of the model are I (1).

\section{Engle Granger Regression Results}

In this research study, we estimated three different regression models which were included for different independent variables. The regression results for different models of the study are given in Table- 4 . 
Table 4: The Regression Result of the Selected Models

\begin{tabular}{|l|c|c|c|}
\hline \multirow{2}{*}{$\begin{array}{l}\text { Independent } \\
\text { variables }\end{array}$} & \multicolumn{3}{|c|}{$\begin{array}{c}\text { Dependent Variable = Gross Domestic Product at } \\
\text { Constant Factor Cost }\end{array}$} \\
\cline { 2 - 4 } & Model-1 & Model-2 & Model-3 \\
\hline C & $8.69(25.22)^{*}$ & $12.68(28.57)^{*}$ & $12.67(33.48)^{*}$ \\
\hline LNGFCF & $0.04(0.65)$ & $0.04(2.69)^{* *}$ & $0.04(2.26)^{* *}$ \\
\hline LNLR & $1.63(9.48)^{*}$ & $0.35(1.99)^{* * *}$ & $0.28(1.90)^{* * *}$ \\
\hline LNSSER & & $0.66(9.93)^{*}$ & $0.54(7.61)^{*}$ \\
\hline LNPCHE & & & $0.09(3.30)^{*}$ \\
\hline & & & \\
\hline R-square & 0.938 & 0.988 & 0.991 \\
\hline Adjusted R-square & 0.933 & 0.986 & 0.990 \\
\hline F-statistic & 189.73 & 660.46 & 693.48 \\
\hline SC & -1.70 & -3.22 & -3.48 \\
\hline
\end{tabular}

Note: The bracket values are t-test values. The *,**, and *** represents 1

$\%, 5 \%$, and $10 \%$ level of significance.

$1 \%$ level of significance represents $99 \%$ of confidence level.

$5 \%$ level of significance represents $95 \%$ of confidence level.

$10 \%$ level of significance represents $90 \%$ of confidence level.

Model-1: In model-1, we have two independent variables i.e. Domestic investment and literacy rate of the country. Dependent variable of the model is gross domestic product. The results reveal that the coefficient of domestic investment is with positive expected signs. The value of $t$-statistics against domestic investment is very low, indicates that the coefficient is statistically insignificant.

However, the coefficient of literacy rate is of value 1.63 which is positive. The t-test value against literacy rate is very high i.e. 9.48. This indicates that the coefficient of literacy rate is statistically significant. Thus a 1 percent change in literacy rate can increase domestic output by 1.63 percent. We can say that when the population is educated then the per-capita income will be high, because of the more productivity in the economy. Moreover, the value of R-square (0.938) indicates that the explanatory power of the model is good.

Model-2: In model-2, we have three independent variables i.e. domestic investment, literacy rate and secondary school enrollment rate. The conclusion reveals that the coefficient of domestic investment is with positive expected sign of value 0.05 . The value of $t$-statistics against 
domestic investment is 2.69 , which indicates that the coefficient is statistically significant at five percent. The coefficient of literacy rate is of value 0.35 and the t-test value is 1.99 . Accordingly, the coefficient of literacy rate is significant at 10 percent. The results indicate that one percent change in literacy rate will change domestic output by 0.35 percent.

However, the coefficient of secondary school enrollment rate value is 0.66 which is also with positive sign. The t-test value against secondary school enrollment rate is very high which is of value 9.93. This interpretation indicates that the coefficient of secondary school enrollment rate is statistically significant at one percent. Thus a 1 percent change in secondary school enrollment rate can increases domestic output by 0.66 percent. We can say that when the investment in the education increases then the literacy rate will increase, when literacy rate increase then the productivity will increase, when the productivity increases in the economy then there will be also per-capita income increases. The value of R-square is 0.988 which expresses that the explanatory power of the model is very good.

Model-3: In model-3, we have four independent variables i.e. domestic investment, literacy rate, and Secondary school enrollment rate, and percapita health expenditure. The results reveal that the coefficient of domestic investment is expected a positive sign of value is 0.04 . The value of $t-$ statistics against domestic investment is 2.26 , which indicates that the coefficient is statistically significant at 5 percent. The coefficient of literacy rate is of value 0.28 and the t-test value is 1.90 . Accordingly, the coefficient of literacy rate is significant at 10 percent. The outcomes indicate that one percent change in literacy rate will change domestic output by 0.28 percent. The coefficient of per-capita health expenditure is of value 0.09 and t-test value is 3.30. Accordingly, the coefficient of per-capita health expenditure is significant at one percent but t-test value is less than the secondary school enrollment rate. However, the coefficient of secondary school enrollment rate value is 0.54 which is with positive sign. The t-test value against secondary school enrollment rate is very high i.e. 7.61. Thus, it is clear from the interpretation that the coefficient of secondary school enrollment rate is significant at one percent. A 1 percent change in secondary school, enrollment rate can increase domestic output by 0.54 . We can say that when investment in the education increases then literacy rate increase. When education increases then per-capita income increases. When per-capita income increases, then per-capita health expenditure increases. The value of $\mathrm{R}$-square is (0.991) which indicates that the 99 percent changes in domestic output are explained by the changes in independent variables of the model. 
Finally, the residuals from last regression or final selected model of the study are tested against unit root. EG model suggests that there is cointegration or a long term connection among the variables, if the residuals of the regression are stationary at level.

\section{Table 5: ADF test Results of Residual of the Final Regression}

\begin{tabular}{|l|c|c|c|}
\hline & & t-Statistic & Prob.* \\
\hline \multicolumn{2}{|l|}{ Augmented Dickey-Fuller test statistic } & -3.668669 & 0.0108 \\
\hline Test critical values: & $1 \%$ level & -3.699871 & \\
\hline & $5 \%$ level & -2.976263 & \\
\hline & $10 \%$ level & -2.627420 & \\
\hline
\end{tabular}

Therefore, the residuals of the model are constructed and then tested for unit root using augmented dickey fuller test. The results are given in Table5. By looking at results in table-5, it is obvious that the residuals are stationary at level. As the t-test is of value -3.669 and the critical value at five percent is -2.976 , while p-value is 0.018 . Thus, the results illustrate that the residuals are stationary at 5 percent level of significance. There is no unit in the residuals of the model. So, it is confirmed that in the model the longterm variables are interconnected with each other.

\section{Conclusion}

To investigate the impact of human capital and physical capital on economic development of the Pakistan, this study used data for the period of 1980 to 2016. Furthermore, we employed ADF test for unit root analysis and Engle Granger approach for estimating long run relationship. The outcomes point out that all variable of the study are non-stationary at level while stationary after first difference. Alternatively, at level variables are I (0) and at first difference variables are I (1). The regression determines that both human capital and physical capital have positive influence on domestic output of the country. An increase in human capital will cause to increase domestic output. Similarly, the increase in physical capital will lead to increase domestic output. The findings of study show that gross fixed capital formation (Physical capital) and per-capita health expenditure, literacy rate and secondary school enrolment rate (Human capital) have a positive role in the development of the country or in increase of the country's GDP. The evidences also show that both human capital and physical capital have a significant impact on the welfare of the economy. Thus, both the 
investments are effective for the economy while investment in education is relatively more effective as per result of the study. If the country wants to increase the domestic output level, so for that the Government should allocate budget equally and also to encourage the investors to invest in health sector as well as in education sector to promote the economy. In Pakistan there are several natural resources which will be very effective for the economic growth. The Government was to make policies and to advance in the human and physical capital to gain benefits from the nature. So for that the Government should invest in the natural resources as well.

\section{References}

Agiomirgianakis, G., Asteriou, D., \& Monastiriotis, V. (2002). Human capital and economic growth revisited: A dynamic panel data study. International advances in economic research, 8(3), 177-187.

Amjad, R., ul Haque, N., \& Colclough, C. (2005). Skills and Competitiveness: Can Pakistan Break Out of the Low-level Skills Trap? The Pakistan Development Review, 387-409.

Anderson, D. (1990). Investment and economic growth. World Development, 18(8), 1057-1079.

Aschauer, D.A. (1989). Does public capital crowd out private capital? Journal of monetary economics, 24(2), 171-188.

Aschauer, D.A. (1989). Is public expenditure productive? Journal of monetary economics, 23(2), 177-200.

Azam, M. \& Ahmad, M.A., (2015). Role of human capital and foreign direct investment in promoting economic growth: evidence from Commonwealth of Independent States. International Journal of Social Economics, 42(2), 89-111

Azam, M., \& Ahmed, A. (2010). The role of human capital in economic development: Evidence from Pakistan: 1961-2009. Interdisciplinary Journal of Contemporary Research in Business, 2(4), 220-233.

Bakar, N. A A., Haseeb, M., \& Azam, M., (2014). The nexus between education and economic growth in Malaysia: cointegration and TodaYamamoto causality approach. Actual Problems of Economics, 12(162), 131-141

Bils, M., \&Klenow, P.J. (2000). Does schooling cause growth? American economic review, 90(5), 1160-1183.

Blankenau, W.F., \& Simpson, N.B. (2004). Public education expenditures and growth. Journal of development economics, 73(2), 583-605. 
Bloom, D.E., \& Canning, D. (2000). The health and wealth of nations. Science, 287(5456), 1207-1209.

Bloom, D., \& Canning, D. (2003). The health and poverty of nations: from theory to practice. Journal of Human Development, 4(1), 47-71.

Falki, N. (2009). Impact of foreign direct investment on economic growth in Pakistan. International Review of Business Research Papers, 5(5), 110120.

Iqbal, Z., \& Zahid, G.M. (1998). Macroeconomic determinants of economic growth in Pakistan. The Pakistan Development Review, 125-148.

Khan, M.S., \& Reinhart, C.M. (1990). Private investment and economic growth in developing countries. World development, 18(1), 19-27.

Khan, M.S., Amjad, R., \& Din, M.U. (2005). Human Capital and Economic Growth in Pakistan. The Pakistan development review, 455-478.

Khan, A.Q., Hafeez, M.H., Saleem, N., \& Azam, M. (2018). Exploring the impact of financial development on inequality: evidence from Three Asian Countries. Review of Economics and Development Studies, 4(2), 334-355.

Lucas Jr, R.E. (1988). On the mechanics of economic development. Journal of monetary economics, 22(1), 3-42.

Lucas, R.E. (1990). Why doesn't capital flow from rich to poor countries?. The American Economic Review, 80(2), 92-96.

Mankiw, N.G., Romer, D., \& Weil, D.N. (1992). A contribution to the empirics of economic growth. The quarterly journal of economics, 107(2), 407-437.

Mittnik, S., \& Neumann, T. (2001). Dynamic effects of public investment: Vector autoregressive evidence from six industrialized countries. Empirical Economics, 26(2), 429-446.

Muhammad, A., \& Saleem, K., (2018). Inflation and the economic growth: evidence from Five Asian Countries. Pakistan Journal of Applied Economics, 28(2), 235-252

Qadri, F.S., \& Waheed, A. (2011). Human capital and economic growth: Time series evidence from Pakistan. Pakistan Business Review, 815833.

Rehman, Z, Tariq, M, \& Azam, M. (2018). The role of human capital in economic development in the selected Central Asian countries. The Dialogue, XIII(03), 235-244

Romer, P.M. (1986). Increasing returns and long-run growth. Journal of political economy, 94(5), 1002-1037. 
Sachs, J.D., Warner, A., Åslund, A., \& Fischer, S. (1995). Economic reform and the process of global integration. Brookings papers on economic activity, 1995(1), 1-118.

Shuaib, I.M., \& Peter, A.O. (2010). Principles of Public Finance: Modern Trend. Auchi-Edo State, Prosper Prints, 137-138.

Solow, R.M. (1956). A contribution to the theory of economic growth. The quarterly journal of economics, 70(1), 65-94. 